\title{
Médiévales
}

Langues, Textes, Histoire

76 | printemps 2019

Du nouveau en archives

\section{Les premiers registres de délibérations municipales tenus dans les villes champenoises : enjeux politiques et innovations documentaires $\left(\mathrm{XV}^{\mathrm{e}}\right.$ siècle)}

First registers of municipal deliberations held in towns in the province of Champagne: Political issues and documentary innovations (fifteenth century)

\section{Cléo Rager}

\section{OpenEdition}

\section{Journals}

Édition électronique

URL : https://journals.openedition.org/medievales/9941

DOI : 10.4000/medievales.9941

ISSN : 1777-5892

\section{Éditeur}

Presses universitaires de Vincennes

\section{Édition imprimée}

Date de publication : 5 septembre 2019

Pagination : 93-112

ISBN : 978-2-37924-028-7

ISSN : 0751-2708

\section{Référence électronique}

Cléo Rager, «Les premiers registres de délibérations municipales tenus dans les villes champenoises enjeux politiques et innovations documentaires (xve siècle) », Médiévales [En ligne], 76 | printemps 2019, mis en ligne le 01 janvier 2021, consulté le 23 avril 2022. URL : http://journals.openedition.org/ medievales/9941 ; DOI : https://doi.org/10.4000/medievales.9941 


\title{
Cléo Rager
}

\section{Les premiers registres de délibérations municipales tenus dans les villes champenoises}

\author{
Enjeux politiques et innovations documentaires ( $X V^{\text {e }}$ siècle)
}

Dans un article évoquant la production des registres de justice seigneuriale, Olivier Guyotjeannin formule l'hypothèse, «purement gratuite » selon lui, que « l'impact des pratiques des juridictions royales, Châtelet et bailliages en tête, a été considérable dans ce processus, comme a été considérable, au même moment, le rôle de l'administration royale dans la diffusion de modèles comptables vers les villes et les seigneuries ${ }^{1}{ }^{1}$. Nous souhaiterions revenir sur cette question de l'influence royale pour un autre type de documents rédigés en nombre croissant dans les villes pour la même période et souvent associés aux comptabilités, à savoir les registres de délibérations municipales ${ }^{2}$. Pour étudier plus spécifiquement cette question de l'innovation documentaire, nous nous pencherons sur les premiers registres champenois, dont la rédaction s'amorce sur une courte période allant de 1417 à 1429, conservés aujourd'hui aux archives municipales des villes de Châlons-en-Champagne, Reims et Troyes. Précisons d'emblée

1. O. GuYotjeannin, "Les registres des justices seigneuriales de la France septentrionale (XIII ${ }^{\mathrm{e}}$-début XVI ${ }^{\mathrm{e}}$ siècle) », dans G. NICOLAJ éd., La diplomatica dei documenti giudiziari (dai placiti agli acta-secc. XII-XV), Rome, 2004, p. 60, cité par P. BERTRAND, Les Écritures ordinaires. Sociologie d'un temps de révolution documentaire (entre royaume de France et empire, 1250-1350), Paris, 2015, p. 271. À propos des registres comptables, ce dernier écrit lui-même que « la mise en œuvre des comptabilités est imposée par le roi, pour les villes du Nord, à partir de 1260-1262 » et en appelle à « une enquête sur ces relations entre le roi de France et ses villes, autour des comptabilités du Nord [...]. Le contrôle des comptes par les princes, dès la seconde moitié du XIII ${ }^{\mathrm{e}}$ siècle, constitue probablement à la fois la raison de cette innovation comptable comme son contrepoint douloureux. »

2. Dans le cadre d'une mission menée à l'Institut de recherche et d'histoire des textes depuis 2013, l'analyse et la comparaison de nombreux registres de ce type, produits dans des villes de la moitié nord de la France, m'ont précédemment permis de mettre au jour la grande hétérogénéité de ces manuscrits, dans le contenu comme dans la forme, et de remettre en cause l'idée d'un modèle et d'une définition précise du « registre de délibérations municipales » dans la France du Nord des XIV et XV siècles. 